\title{
The protein flexibility in receptor-ligand docking simulations
}

\author{
Frank Tristram \\ From 5th German Conference on Cheminformatics: 23. CIC-Workshop \\ Goslar, Germany. 8-10 November 2009
}

Many small-molecule drugs work by binding specifically to a target protein in the cell. It is known for over a century that both the ligand and protein receptor change their conformation in the association process, which is called the induced-fit effect. Ligand conformational change is routinely treated in methods for insilico drug discovery, because typical drug molecules have seldom more than 100 atoms. The flexibility of proteins, which often have more than 10000 atoms, is much harder to treat and was therefore neglected in most high-speed docking methods, limiting their accuracy and predictive value.

In this project we have developed an efficient numerical search procedure that succeeds to model the interaction between a flexible ligand and important flexible parts of the protein in a computationally affordable protocol. Our virtual screening software FlexScreen thus minimizes the total interaction energy of the emerging protein-ligand complex including flexible backbone regions. We have demonstrated the reliability and accuracy of this approach on several examples, for which at least two different receptor-conformations have been experimentally observed. We succeeded to predict the correct binding pose of a protein-ligand complex starting from the crystal structure of an unrelated protein conformation, where large conformational changes of

Institute of Nanotechnology, Karlsruhe Institute of Technology, Hermannvon-Helmholtz-Platz 1, 76344 Eggenstein-Leopoldshafen, Germany the protein are necessary to bind the ligand. Correctly predicting such conformational changes makes our approach attractive for virtual screening of medium sized databases, in particular for kinases and other target receptors which have flexible binding pockets.

Published: 4 May 2010

doi:10.1186/1758-2946-2-S1-011

Cite this article as: Tristram: The protein flexibility in receptor-ligand docking simulations. Journal of Cheminformatics 2010 2(Suppl 1):011.
Publish with ChemistryCentral and every scientist can read your work free of charge
"Open access provides opportunities to our colleagues in other parts of the globe, by allowing anyone to view the content free of charge." W. Jeffery Hurst, The Hershey Company.
- available free of charge to the entire scientific community
- peer reviewed and published immediately upon acceptance
- cited in PubMed and archived on PubMed Central
- yours - you keep the copyright
Submit your manuscript here:
http://www.chemistrycentral.com/manuscript/

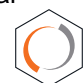 ChemistryCentral

